University of Nebraska - Lincoln DigitalCommons@University of Nebraska - Lincoln

Papers in Plant Pathology

Plant Pathology Department

2017

\title{
Wheat streak mosaic virus coat protein is a host- specific long-distance transport determinant in oat
}

Satyanarayana Tatineni

USDA-ARS, Satyanarayana.Tatineni@ars.usda.gov

Follow this and additional works at: http:// digitalcommons.unl.edu/plantpathpapers

Part of the Other Plant Sciences Commons, Plant Biology Commons, and the Plant Pathology Commons

Tatineni, Satyanarayana, "Wheat streak mosaic virus coat protein is a host-specific long-distance transport determinant in oat" (2017). Papers in Plant Pathology. 475.

http://digitalcommons.unl.edu/plantpathpapers/475

This Article is brought to you for free and open access by the Plant Pathology Department at DigitalCommons@University of Nebraska - Lincoln. It has been accepted for inclusion in Papers in Plant Pathology by an authorized administrator of DigitalCommons@University of Nebraska - Lincoln. 
Short communication

\title{
Wheat streak mosaic virus coat protein is a host-specific long-distance transport determinant in oat
}

\author{
Satyanarayana Tatineni \\ United States Department of Agriculture-Agricultural Research Service and Department of Plant Pathology, University of Nebraska-Lincoln, Lincoln, NE 68583, United \\ States
}

\section{A R T I C L E I N F O}

\section{Keywords:}

Wheat streak mosaic virus

Wheat

Potyviridae

Oat

Coat protein

Long-distance transport

\begin{abstract}
A B S T R A C T
Viral determinants involved in systemic infection of hosts by monocot-infecting plant viruses are poorly understood. Wheat streak mosaic virus (WSMV, genus Tritimovirus, family Potyviridae) exclusively infects monocotyledonous crops such as wheat, oat, barley, maize, triticale, and rye. Previously, we reported that WSMV CP amino acids 36-84 are expendable for systemic infection of wheat, maize, barley and rye. In this study, the role of coat protein (CP) in systemic infection of oat by WSMV was examined by using a series of viable deletion mutants. WSMV bearing deletions within or encompassing all of amino acids 36-57 efficiently infected oat, indicating that these amino acids are dispensable for systemic infection of oat. However, WSMV mutants lacking CP amino acids 58-84 or 85-100 failed to systemically infect oat. Furthermore, green fluorescent protein-tagged WSMV mutants lacking CP amino acids 58-100 elicited local foci in oat but failed to enter the vasculature. These data suggest that CP amino acids 58-100 are required for systemic infection of oat by WSMV by specifically facilitating virus long-distance transport in oat.
\end{abstract}

Successful interactions between viral and host factors for viral replication, cell-to-cell and long-distance movement, and suppression of host defense mechanisms could facilitate infection of wide range of hosts by viruses (Benitez-Alfonso et al., 2010; Lucas et al., 2009; Nelson and Citovsky, 2005; Voinnet et al., 1999). Systemic infection of plants by viruses requires a sequence of events such as virus replication in initially infected cells, followed by cell-to-cell movement to adjacent cells through plasmodesmata, and multistep long-distance transport through the vasculature (Carrington et al., 1996; Heinlein, 2015; Lucas, 2006; Waigmann et al., 2004). In contrast to cell-to-cell movement, viral long-distance transport through the vasculature is more complex and involves passive transport of viruses along with photosynthates from source to sink tissues, followed by unloading at distal ends through veins (Harries et al., 2010; Hipper et al., 2013; Waigmann et al., 2004). Following these events, successive cycles of cell-to-cell and long-distance movement facilitate the establishment of virus infection throughout plants.

Wheat streak mosaic virus (WSMV), the most economically important virus in the Great Plains region of the USA, exclusively infects monocotyledonous crops such as wheat (Triticum aestivum L.), oat (Avena sativa L.), maize (Zea mays L.), barley (Hordeum vulgare L.), rye (Secale cereale L.), and Triticale [ $\times$ Triticosecale Wittmack] (Brakke, 1987; French and Stenger, 2004; Wegulo et al., 2008). WSMV is the type species of the genus Tritimovirus of the family Potyviridae, and has a 9384-nucleotide (nt) [excluding the $3^{\prime}$ poly (A) tail] single-stranded RNA genome, organized into a large open reading frame encoding a polyprotein of 3035 amino acids (Stenger et al., 1998). The polyprotein is processed into at least 10 mature proteins by the three virus-encoded P1, HC-Pro, and NIa-Pro proteinases (Stenger et al., 1998). WSMV is transmitted by the wheat curl mite (Aceria tosichella Keifer) (Slykhuis, 1955). HC-Pro of WSMV is dispensable for systemic infection of wheat, but both HC-Pro and coat protein (CP) are required for wheat curl mite transmission (Stenger et al., 2005a,b; Tatineni, unpublished data). In contrast to HC-Pro of members of the genus Potyvirus (Kasschau and Carrington, 1998), P1 of WSMV was identified as a suppressor of RNA silencing (Young et al., 2012). Recently, both CP and NIa-Pro of WSMV were identified as determinants of superinfection exclusion (Tatineni and French, 2016).

The members of the family Potyviridae do not encode a dedicated movement protein; instead, several virus-encoded proteins have been implicated in virus movement with at least one other function in the virus infection cycle. The HC-Pro, CP, CI, VPg, and P3N-PIPO cistrons have been reported to be involved in cell-to-cell movement of potyvirids (Revers and Garcia, 2015). Compared to cell-to-cell movement determinants of potyvirids, the long-distance transport determinants are poorly studied. HC-Pro and NIa-VPg are involved in long-distance movement of plum pox virus and potato virus A, respectively (Rajamäki and Valkonen, 1999; Sáenz et al., 2002).

E-mail address: Satyanarayana.tatineni@ars.usda.gov. 


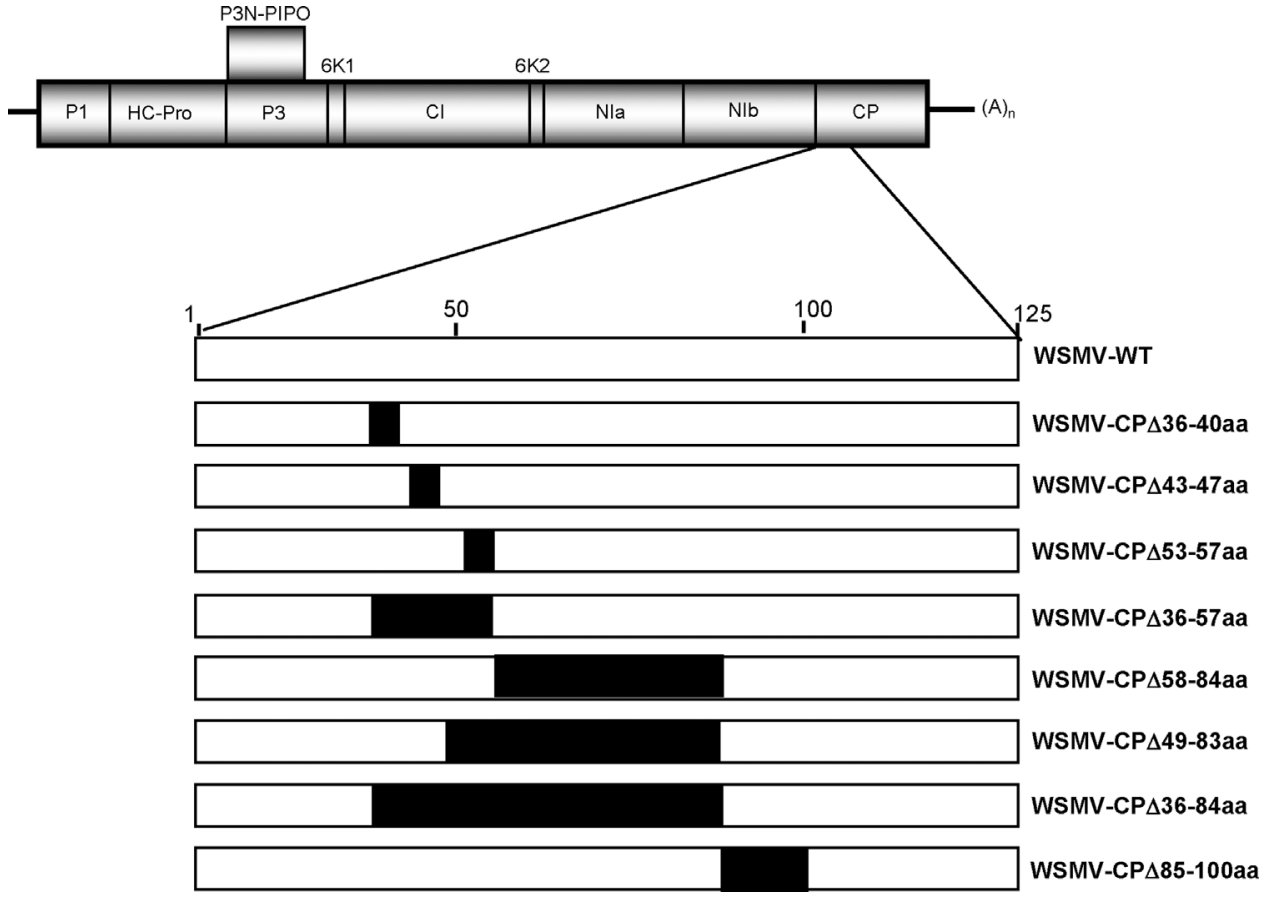

A

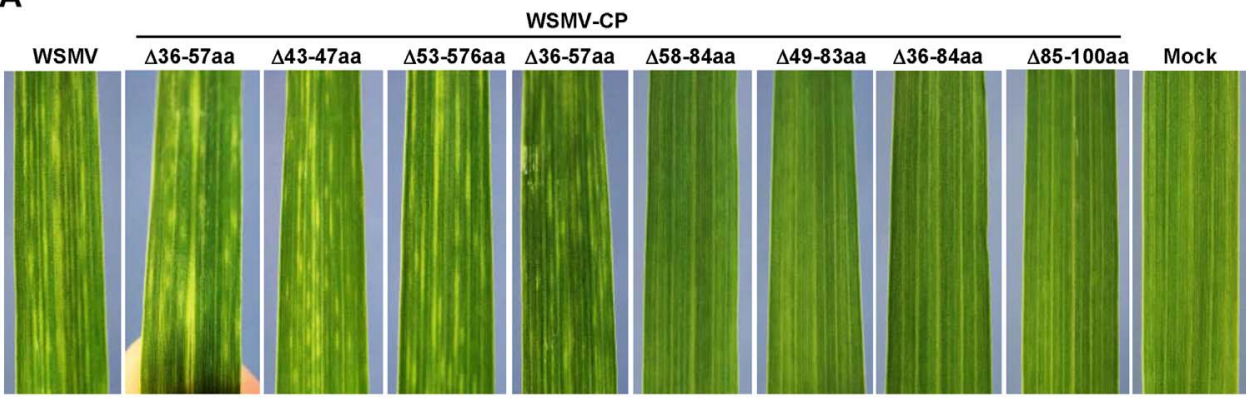

B

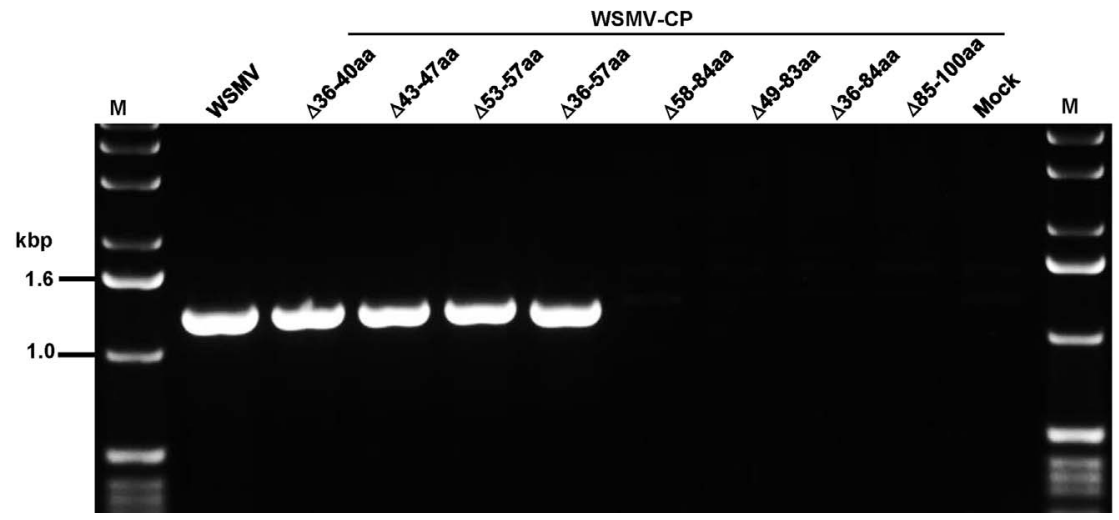

Fig. 1. Genomic organization of wheat streak mosaic virus (WSMV) with proteins encoded by the genome. An expanded view of the N-terminal 125 amino acids of coat protein (CP) and introduced deletions in the $\mathrm{CP}$ cistron is shown at the bottom of the genome. The positions of deleted amino acids in the $\mathrm{CP}$ are indicated with solid boxes, and were described previously in Tatineni et al. (2014, 2017).
Fig. 2. Wheat streak mosaic virus (WSMV) coat protein (CP) amino acids $58-100$ are required for systemic infection of oat (Avena sativa L.). A. Symptoms elicited by WSMV wild-type or WSMV CP deletion mutants in upper noninoculated leaves of oat at 21 days postinoculation (dpi). Mock: Buffer inoculated oat. Crude sap from wheat leaves infected with WSMV or its CP deletion mutants at 1:20 dilution in $20 \mathrm{mM}$ sodium phosphate buffer, $\mathrm{pH} 7.0$ was used as inocula for oat seedlings at the two-leaf stage. B. Reverse transcription-polymerase chain reaction of CP cistron from total RNA extracted from upper systemic leaves of oat inoculated with wildtype WSMV or its CP deletion mutants at $21 \mathrm{dpi}$. Mock: oat inoculated with buffer. M: $1.0 \mathrm{kbp}$ DNA ladder. Note that WSMV with deletions comprising amino acids 58-100 are failed to infect oat systemically.
In contrast to other viral CPs, WSMV CP is unusually tolerated extensive point and deletion mutations for systemic infection of wheat (Tatineni and French, 2014; Tatineni et al., 2014). Availability of these deletion and point mutants facilitated mapping of CP determinants involved in wheat curl mite transmission and cell-to-cell and long-distance movement (Tatineni et al., 2011a, 2014; Tatineni and French, 2014; Tatineni, unpublished data). The $\mathrm{N}$ - and C-terminal regions of CP is required for systemic infection of maize inbred line SDp2, and amino acids 6-27 and 85-100 are required for efficient virion assembly and cell-to-cell movement (Tatineni et al., 2011a, 2014; Tatineni and French, 2014). The amino-proximal amino acids 36-84 are expendable for virion assembly and systemic infection of wheat, while the carboxyterminal 65 amino acids are dispensable for virion assembly, but are required for cell-to-cell movement (Tatineni et al., 2014). Recently, it has been demonstrated that WSMV with deletions comprising CP amino acids 36-84 efficiently infected wheat, maize inbred line SDp2, barley cv. Metcalfe, and rye cv. Petkus (Tatineni et al., 2017). However, ability of these CP deletion mutants infecting oat plants is not known. Availability of a series of WSMV CP mutants bearing deletions within amino acids 36-100 (Fig. 1) facilitates examination of the requirements of $\mathrm{CP}$ for systemic infection of oat.

In vitro transcripts of WSMV-S81 (wild-type) (Choi et al., 1999), 
Table 1

Wheat streak mosaic virus (WSMV) coat protein (CP) amino acids 58-100 are required for systemic infection of oat cv. Proat. ${ }^{\text {a }}$

\begin{tabular}{lllr}
\hline \multirow{2}{*}{ Mutant } & \multicolumn{2}{l}{ \#of oat } & \% oat infected \\
\cline { 2 - 3 } & inoculated & infected & \\
\hline WSMV-S81 & 15 & 14 & 93 \\
WSMM-CP $\Delta 36-40$ aa & 16 & 15 & 94 \\
WSMM-CP $\Delta 43-47$ aa & 18 & 18 & 100 \\
WSMM-CP $\triangle 53-57$ aa & 16 & 16 & 100 \\
WSMM-CP $\Delta 36-57$ aa & 17 & 16 & 94 \\
WSMM-CP $\Delta 58-84$ aa & 14 & 0 & 0 \\
WSMM-CP $\Delta 49-83$ aa & 14 & 0 & 0 \\
WSMM-CP $\Delta 36-84$ aa & 16 & 0 & 0 \\
WSMM-CP $\Delta 85-100$ aa & 17 & 0 & 0 \\
Mock & 12 & 0 & 0
\end{tabular}

a Oat seedlings inoculated at the two-leaf stage with crude sap from wheat leaves infected with in vitro transcripts of wild-type virus or with CP deletion mutants. Inoculated oat plants were scored for symptom development at 21 days post inoculation.

WSMV-CP $\Delta 36-84$ aa and WSMV-CP $\Delta 85-100$ aa (Tatineni et al., 2014), and WSMV-CP $\Delta 36-40 \mathrm{aa}$, WSMV-CP $\Delta 43-47 \mathrm{aa}$, WSMV-CP $\Delta 53-57 \mathrm{aa}$, WSMV-CP $\Delta 36-57 \mathrm{aa}$, WSMV-CP $\Delta 58-84 \mathrm{aa}$, and WSMV-CP $\Delta 49-83 \mathrm{aa}$ (Tatineni et al., 2017) (Fig. 1) were inoculated onto wheat seedlings (cv. Tomahawk) at the single-leaf stage as described in Tatineni et al. (2011b). Wheat infected with WSMV CP deletion mutants were harvested at 14 days postinoculation (dpi) and stored at $-20{ }^{\circ} \mathrm{C}$ for future use or directly inoculated onto oat cv. Proat at the two-leaf stage. In order to ensure efficient infection of oat, crude sap from wheat leaves infected with in vitro transcripts of $\mathrm{CP}$ deletion mutants was used to mechanically inoculate oat seedlings. Inoculated oat seedlings were incubated in a greenhouse at $24-27^{\circ} \mathrm{C}$ max and $20-22{ }^{\circ} \mathrm{C}$ min temperature with $14 \mathrm{~h}$ daylight or supplemental light for symptom development. At $21 \mathrm{dpi}$, WSMV mutants with deletion of individual SGSGS motifs (flexible linker) located at amino acid positions 36-40, 43-47, or $53-57$ in the CP cistron efficiently infected oat at $94-100 \%$ with chlorotic streaks and mosaic symptoms similar to those of wild-type virus (Fig. 2A; Table 1). These data indicate that individual SGSGS motifs located between amino acids $36-57$ in $\mathrm{CP}$ are dispensable for systemic infection of oat by WSMV. WSMV with a deletion of CP amino acids 36-57 comprising all three SGSGS motifs also infected $94 \%$ of oat plants and elicited systemic symptoms similar to those of wild-type virus (Fig. 2A; Table 1). Recently, it has been found that this region of $\mathrm{CP}$ is also dispensable for systemic infection of wheat, barley, maize inbred line SDp2, and rye (Tatineni et al., 2017).

WSMV mutants bearing deletions comprising CP amino acids 58-84 accumulated at elevated levels and caused more severe symptoms in wheat, maize inbred line SDp2, barley, and rye compared to wild-type virus (Tatineni et al., 2017). The requirement of these amino acids for oat infection was examined by inoculating oat seedlings with WSMV mutants containing deletion of amino acids $58-84$, $49-83$, or $36-84$. At $21 \mathrm{dpi}$, none of these mutants elicited systemic symptoms (Fig. 2A; Table 1), suggesting that $\mathrm{CP}$ amino acids 58-84 are required for systemic infection of oat. Next, the requirement of CP amino acids 85-100 for systemic infection of oat was examined by inoculating oat seedlings with WSMV-CP $\triangle 85-100 \mathrm{aa}$. This deletion mutant also failed to infect oat at 21 dpi (Fig. 2A; Table 1), suggesting that CP amino acids 85-100 are also required for systemic infection of oat. Previously, Tatineni et al. (2014) reported that CP amino acids 85-100 are required for efficient virion assembly and cell-to-cell movement of WSMV; however, a mutant with deletion of these amino acids efficiently infected wheat with a slight delay in symptom development. Taken together, these data revealed that CP amino acids 58-100, but not $36-57$, are essential for systemic infection of oat by WSMV.

It is possible that WSMV mutants with deletions comprising CP amino acids 58-100 might have caused symptomless infection in oat. To exclude this possibility, total RNA extracted from upper systemic leaves of oat inoculated with CP deletion mutants at $21 \mathrm{dpi}$ was used for first-strand cDNA synthesis with random primers (Promega, Madison, WI), followed by PCR using a forward primer XV1 (corresponding to nts 8096-8121) and a reverse primer XC1 (complementary to nt 9373-9348) flanking the CP cistron (McNeil et al., 1996; Tatineni et al., 2014). Analyses of RT-PCR products by agarose gel electrophoresis revealed that expected sized products were obtained from oat plants inoculated with WSMV mutants bearing deletions within or all of amino acids 36-57. However, no RT-PCR product was amplified from oat inoculated with mutants lacking amino acids 58-100 (Fig. 2B). These

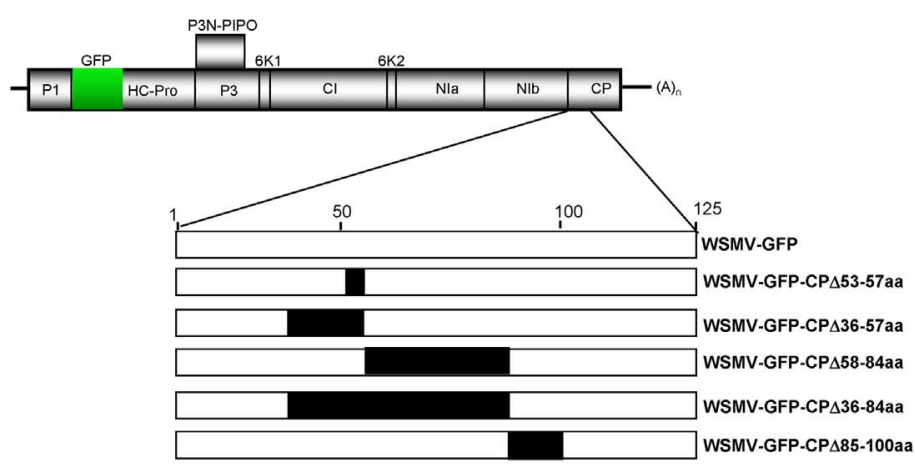

B
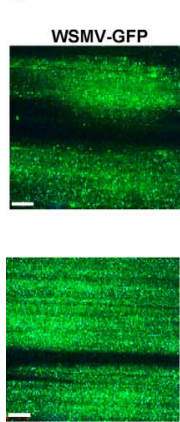

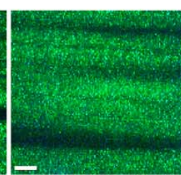

WSMV-GFP-CP.
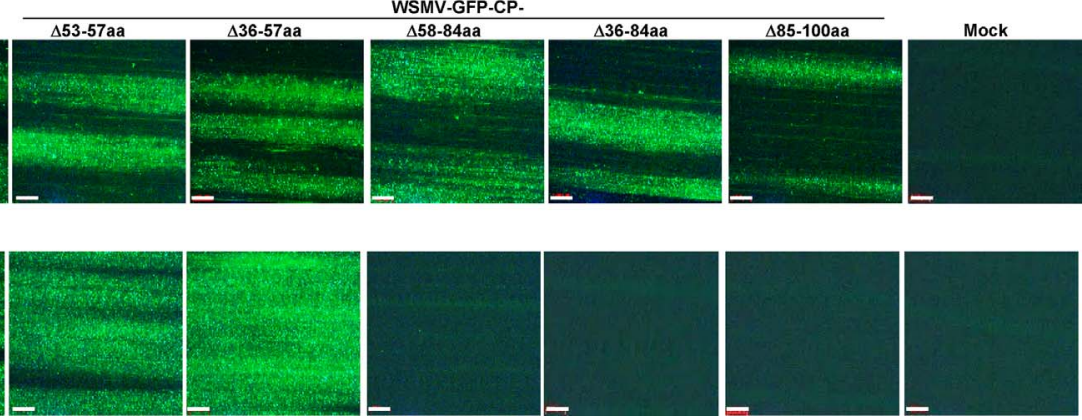
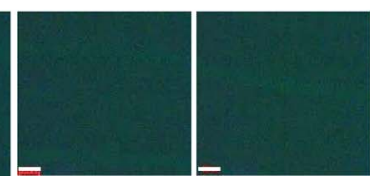

Fig. 3. A. Schematic representation of genomic organization of green fluorescent protein (GFP)-tagged wheat streak mosaic virus (WSMV) with deletions in the CP cistron. Proteins encoded by the WSMV genome are indicated in the large open reading frame. An expanded view of the N-terminal 125 amino acids of coat protein (CP) is indicated at the bottom of schematic representation of WSMV genome. The positions of deleted amino acids in the $\mathrm{CP}$ are indicated with solid boxes. B. Local foci elicited by WSMV-GFP (wild-type virus) and GFPtagged WSMV mutants with deletion of amino acids $53-57,36-57,58-84,36-84$, or $85-100$ at 7 days postinoculation (dpi) (upper panel). Systemic foci in upper noninoculated leaves of oat at $28 \mathrm{dpi}$ (bottom panel). Mock: Buffer inoculated oat. Crude sap from wheat leaves infected with in vitro transcripts of GFPtagged wild-type WSMV or CP deletion mutants at 1 : 20 dilution was used to inoculate oat seedlings at the two-leaf stage. Bars represent $500 \mu \mathrm{m}$. 


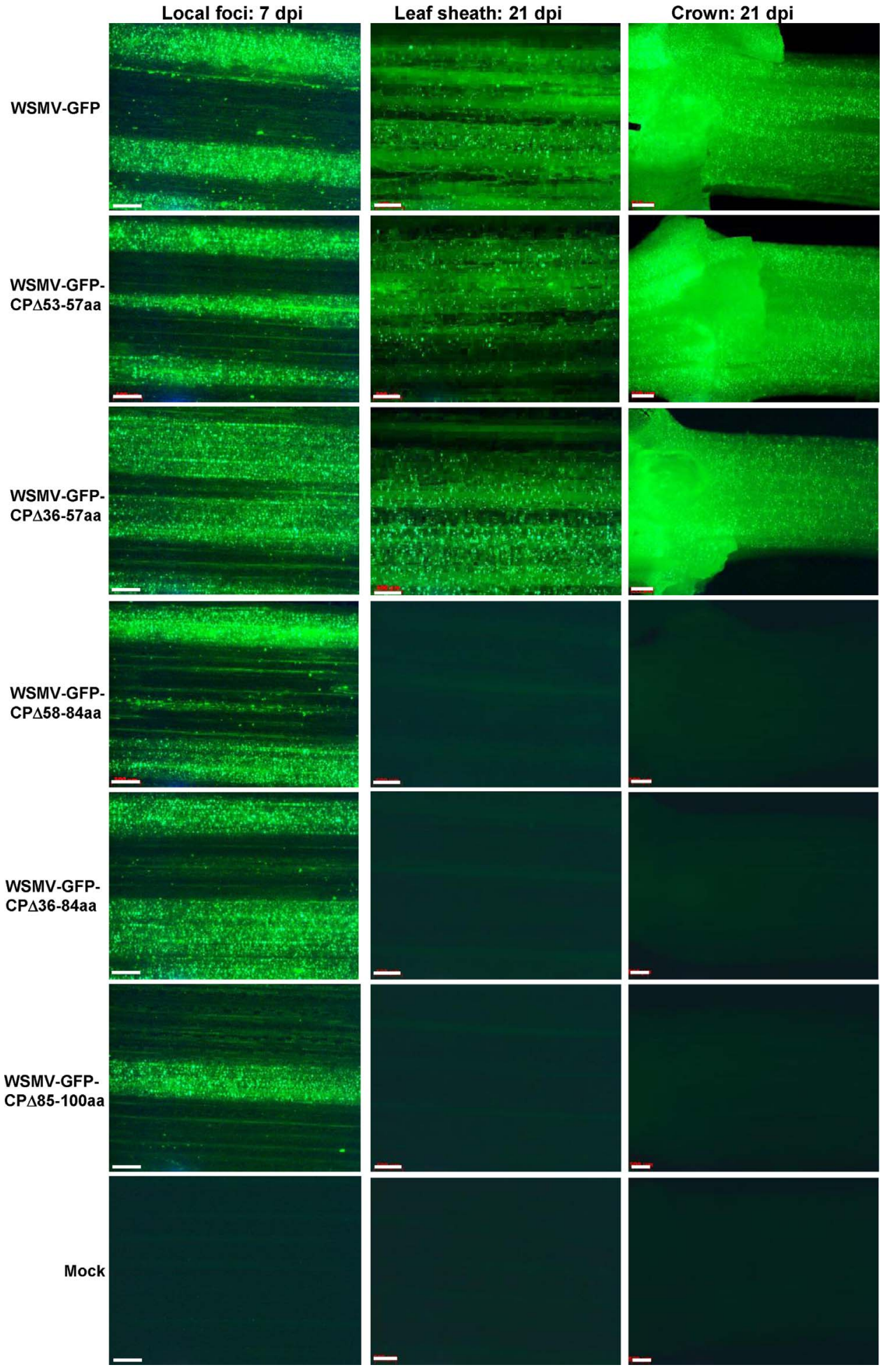

Fig. 4. GFP-tagged wheat streak mosaic virus (WSMV) coat protein (CP) deletion mutants lacking amino acids 58-100 exhibited profound defects in entry into the vasculature of oat. Inoculated leaves and their leaf sheaths, and crowns were observed under a fluorescence microscope for the presence of GFP. Note that all CP deletion mutants elicited foci in inoculated leaves at 7 days postinoculation (dpi). At $21 \mathrm{dpi}$, GFP fluorescence was detected in the leaf sheaths of inoculated leaves and crowns of oat plants inoculated with WSMV mutants lacking CP amino acids $53-57$ or $36-57$, while GFP was not found at detectable levels in oat inoculated with mutants lacking CP amino acids 58-84, 36-84, or 85-100. At least ten inoculated oat plants were observed per mutant under a fluorescence microscope, and representative GFP pictures from a single oat plant are presented. Bars represent $500 \mu \mathrm{m}$. data confirmed that $\mathrm{CP}$ amino acids 58-100 are required for systemic infection of oat by WSMV.

Failure to infect a particular host by a plant virus could be due to its inability to replicate or to move cell-to-cell and/or long-distance (Pallas and Garcia, 2011). WSMV CP is not required for replication (Tatineni et al., 2014); hence, deletion of amino acids 58-100 in CP might have affected cell-to-cell and/or long-distance movement of WSMV in oat. This possibility was examined by using selected CP deletion mutants of a GFP-tagged WSMV (Tatineni et al., 2011b). pSP6-WSMV-GFP-CP $\Delta 53$ 57aa, pSP6-WSMV-GFP-CP $\Delta 36-57$ aa, and pSP6-WSMV-GFP-CP $\Delta 58$ - 84aa were obtained by transferring the BstEII-SpeI fragment (nt 6319 to the $3^{\prime}$ end) from pSP6-WSMV-CP $\Delta 53-57$ aa, pSP6-WSMV-CP $\Delta 36-57$ aa and pSP6-WSMV-CP $\Delta 58-84 \mathrm{aa}$, respectively, into pSP6-WSMV-GFP-6KI/ CI(7aa) (WSMV-GFP; Tatineni et al., 2011b) as described in Tatineni et al. (2014) (Fig. 3A). WSMV-GFP-CP $\Delta 36-84$ aa and WSMV-GFP$\mathrm{CP} \Delta 85-100$ aa were described in Tatineni et al. (2014). Crude sap at 1:20 dilution in $20 \mathrm{mM}$ sodium phosphate buffer, $\mathrm{pH} 7.0$ from wheat infected with in vitro transcripts of GFP-tagged wild-type virus or CP deletion mutants was used to inoculate oat cv. Proat seedlings at the two-leaf stage. GFP fluorescence in inoculated and upper noninoculated 
oat leaves was examined under a Zeiss Stereo Discovery V12 fluorescence microscope (Carl Zeiss MicroImaging, Inc., New York, NJY) using a narrow-band GFP filter set $38 \quad(400-450 \mathrm{~nm}$ excitation and 450-490 nm emission). The GFP fluorescence pictures were captured using an AuxioCam MRc5 camera attached to the fluorescence microscope.

GFP-tagged WSMV mutants comprising deletion of CP amino acids $53-57,36-57,36-84$, or 58-84 elicited local foci similar to that of the wild-type virus at $7 \mathrm{dpi}$ (Fig. 3B, top panel). However, slightly smallersized foci produced by WSMV-GFP-CP $\Delta 85-100$ aa could be due to CP amino acids $85-100$ being required for efficient virion assembly and cell-to-cell movement (Fig. 3B, top panel; Tatineni et al., 2014). These data revealed that $\mathrm{CP}$ deletion mutants facilitated efficient cell-to-cell movement in oat. Oat plants inoculated with GFP-tagged CP deletion mutants were also examined for systemic infection at 28 dpi (Fig. 3B, bottom panel). WSMV mutants with a deletion comprising CP amino acids $53-57$ or $36-57$ elicited systemic foci in upper noninoculated leaves of oat, while mutants lacking amino acids 58-100 did not (Fig. 3B, bottom panel). These data suggest that CP amino acids 58-100 are dispensable for cell-to-cell movement, but are required for longdistance transport of WSMV in oat.

It is possible that failure of WSMV CP deletion mutants to move long-distance in oat could be due to the inability of virus to enter the vasculature or unload from the vasculature at a distant place. Oat seedlings inoculated at the two-leaf stage with crude sap of wheat leaves infected with in vitro transcripts were observed for fluorescent foci in inoculated leaves at $7 \mathrm{dpi}$, and leaf sheaths of inoculated leaves and crowns at $21 \mathrm{dpi}$. WSMV with a deletion comprising amino acids 53-57 or 36-57 efficiently infected leaf sheaths of inoculated leaves and crowns (Fig. 4). In contrast, GFP fluorescence was not found at detectable levels in leaf sheaths and crowns of oat inoculated with WSMV mutants lacking CP amino acids $58-84,36-84$, or $85-100$ (Fig. 4). These data indicate that deletion of CP amino acids 58-100 debilitated WSMV entry into the vasculature of oat. In the same experiment, all CP deletion mutants exhibited efficient cell-to-cell movement in inoculated leaves of oat at $7 \mathrm{dpi}$ (Fig. 4). Similar to results observed in this study, mutations at the $\mathrm{N}$ - and C-terminal regions of WSMV CP failed to infect maize inbred line SDp2 due to profound defects in long-distance transport but not in cell-to-cell movement (Tatineni et al., 2011a; Tatineni and French, 2014). Taken together, these data suggest that WSMV contains multiple host-specific longdistance transport determinants in its capsid protein cistron. Several potyviral proteins have been reported to be involved in extension of host range such as plum pox virus (P1 and HC-Pro; Sáenz et al., 2002; Salvador et al., 2008), tobacco etch virus (VPg; Schaad et al., 1997), potato virus A (6K2 and VPg; Rajamäki and Valkonen, 1999), papaya ringspot virus (NIa-Pro; Chen et al., 2008), and turnip mosaic virus (P3; Suehiro et al., 2004).

Availability of a series of WSMV CP deletion mutants with efficient systemic infection of wheat facilitated examination of the role of $\mathrm{CP}$ in systemic infection of monocotyledonous plants. The present study demonstrated that $\mathrm{CP}$ amino acids $58-100$, but not $36-57$, are required for oat infection, specifically for long-distance transport but not for cell-tocell movement. Collectively, this study together with reports by Tatineni et al. (2011a) and Tatineni and French (2014) revealed that WSMV CP harbors multiple host-specific long-distance transport determinants that are likely to be required for interaction with host factors of different monocot plant species.

\section{Acknowledgments}

We thank Jonathan Horrell and Jeff Alexander for excellent technical assistance. This project was supported in part by funds provided through the United States Department of Agriculture, USDA-NIFA grant number 2013-68004-20358. USDA is an equal opportunity provider and employer. Mention of trade names or commercial products in this publication is solely for the purpose of providing specific information and does not imply recommendation or endorsement by the U.S. Department of Agriculture.

\section{References}

Benitez-Alfonso, Y., Faulkner, C., Ritzenthaler, C., Maule, A.J., 2010. Plasmodesmata: gateways to local and systemic virus infection. Mol. Plant-Microbe Interact. 23, 1403-1412.

Brakke, M.K., 1987. Virus disease in wheat. In: Heyne, E.G. (Ed.), Wheat and Wheat Improvement, 2nd ed. American Society of Agronomy, Crop Science Society of America, Soil Science Society of America Madison, WI, pp. 585-603.

Carrington, J.C., Kasschau, K.D., Mahajan, S.K., Schaad, M.C., 1996. Cell-to-cell and longdistance transport of viruses in plants. Plant Cell 8, 1669-1681.

Chen, K.C., Chiang, C.H., Raja, J.A., Liu, F.L., Tai, C.H., Yeh, S.D., 2008. A single amino acid of NIa-Pro of papaya ringspot virus determines host specificity for infection of papaya. Mol. Plant-Microbe Interact. 21, 1046-1057.

Choi, I.R., French, R., Hein, G.L., Stenger, D.C., 1999. Fully biologically active in vitro transcripts of the eriophyid mite-transmitted wheat streak mosaic tritimovirus. Phytopathology 89, 1182-1185.

French, R., Stenger, D.C., 2004. Wheat streak mosaic virus. In: Lapierre, H., Signoret, P. (Eds.), Viruses and Virus Diseases of Poaceae. INRA Editions, Paris, pp. 602-604.

Harries, P.A., Schoelz, J.E., Nelson, R.S., 2010. Intracellular transport of viruses and their components: utilizing the cytoskeleton and membrane highways. Mol. Plant-Microbe Interact. 23, 1381-1393.

Heinlein, M., 2015. Plant virus replication and movement. Virology 479-480, 657-671.

Hipper, C., Brault, V., Ziegler-Graff, V., Revers, F., 2013. Viral and cellular factors involved in phloem transport of plant viruses. Front. Plant Sci. 4, 154. http://dx.doi. org/10.3389/fpls.2013.00154.

Kasschau, K.D., Carrington, J.C., 1998. A counterdefensive strategy of plant viruses: suppression of posttranscriptional gene silencing. Cell 95, 461-470.

Lucas, W.J., Ham, L.K., Kim, J.Y., 2009. Plasmodesmata-bridging the gap between neighboring plant cells. Trends Cell Biol. 19, 495-503.

Lucas, W.J., 2006. Plant viral movement protein: agents for cell-to-cell trafficking of viral genomes. Virology 344, 169-184.

McNeil, J.E., French, R., Hein, G.L., Baenziger, P.S., Eskridge, K.M., 1996. Characterization of genetic variability among natural populations of wheat streak mosaic virus. Phytopathology 86, 1222-1227.

Nelson, R.S., Citovsky, V., 2005. Plant viruses: invaders of cells and pirates of cellular pathways. Plant Physiol. 138, 1809-1814.

Pallas, V., Garcia, J.A., 2011. How do plant viruses induce disease? Interactions and interference with host components. J. Gen. Virol. 92, 2691-2705.

Rajamäki, M.L., Valkonen, J.P.T., 1999. The 6K2 protein and the VPg of potato virus A are determinants of systemic infection in Nicandra physaloides. Mol. Plant-Microbe Interact. 12, 1074-1081.

Revers, F., Garcia, J.A., 2015. Molecular biology of potyviruses. Adv. Virus Res. 92, 101-199.

Sáenz, P., Salvador, B., Simón-Mateo, C., Kasschau, K.D., Carrington, J.C., García, J.A., 2002. Host-specific involvement of the HC protein in the long-distance movement of potyviruses. J. Virol. 76, 1922-1931.

Salvador, B., Delgadillo, M.O., Sáenz, P., García, J.A., Simón-Mateo, C., 2008. Identification of plum pox virus pathogenicity determinants in herbaceous and woody hosts. Mol. Plant-Microbe Interact. 21, 20-29.

Schaad, M.C., Lellis, A.D., Carrington, J.C., 1997. VPg of tobacco etch potyvirus is a host genotype-specific determinant for long-distance movement. J. Virol. 71, 8624-8631.

Slykhuis, J.T., 1955. Aceria tulipae Keifer (Acarina: Eriophyidae) in relation to spread of wheat streak mosaic virus. Phytopathology 45, 116-128.

Stenger, D.C., Hall, J.S., Choi, I.-R., French, R., 1998. Phylogenetic relationships within the family Potyviridae: wheat streak mosaic virus and brome streak mosaic virus are not members of the genus Rymovirus. Phytopathology 88, 782-787.

Stenger, D.C., French, R., Gildow, F.E., 2005a. Complete deletion of Wheat streak mosaic virus HC-Pro: a null mutant is viable for systemic infection. J. Virol. 79, 12077-12080.

Stenger, D.C., Hein, G.L., Gildow, F.E., Horken, K.M., French, R., 2005b. Plant virus HC Pro is a determinant of eriophyid mite transmission. J. Virol. 79, 9054-9061.

Suehiro, N., Natsuaki, T., Watanabe, T., Okuda, S., 2004. An important determinant of the ability of Turnip mosaic virus to infect Brassica spp. and/or Raphanus sativus is in its P3 protein. J. Gen. Virol. 85, 2087-2098.

Tatineni, S., French, R.C., 2014. The C-terminus of wheat streak mosaic virus coat protein is involved in differential infection of wheat and maize through host-specific longdistance transport. Mol. Plant-Microbe Interact. 27, 150-162.

Tatineni, S., French, R., 2016. The coat protein and NIa protease of two Potyviridae family members independedntly confer superinfection exclusion. J. Virol. 90, 10886-10905.

Tatineni, S., Van Winkle, D.H., French, R., 2011a. The N-terminal region of wheat streak mosaic virus coat protein is a host- and strain-specific long-distance transport factor. J. Virol. 85, 1718-1731.

Tatineni, S., McMechan, J.A., Hein, G.L., French, R., 2011b. Efficient and stable expression of GFP through wheat streak mosaic virus-based vectors in cereal hosts using a range of cleavage sites: formation of dense fluorescent aggregates for sensitive virus tracking. Virology 410, 268-281.

Tatineni, S., Kovacs, F., French, R., 2014. Wheat streak mosaic virus infects systemically despite extensive coat protein deletions: identification of virion assembly and cell-tocell movement determinants. J. Virol. 88, 1366-1380.

Tatineni, S., Elowsky, C., Graybosch, R.A., 2017. Wheat streak mosaic virus coat protein 
deletion mutants elicit more severe symptoms than wild-type virus in multiple cereal hosts. Mol. Plant-Microbe Interact. http://dx.doi.org/10.1094/MPMI-07-17-0182-R. in press.

Voinnet, O., Pinto, Y.M., Baulcombe, D.C., 1999. Suppression of gene silencing: a general strategy used by diverse DNA and RNA viruses of plants. Proc. Natl. Acad. Sci. U. S. A. 96, 14147-14152.

Waigmann, E., Ueki, S., Trutnyeva, K., Citovsky, V., 2004. The ins and outs of nondestructive cell-to-cell and systemic movement of plant viruses. CRC Crit. Rev. Plant Sci. 23, 195-250.

Wegulo, S.N., Hein, G.L., Klein, R.N., French, R., 2008. Managing Wheat Streak Mosaic EC89-1871. University of Nebraska-Lincoln Extension Bulletin.

Young, B.A., Stenger, D.C., Qu, F., Morris, T.J., Tatineni, S., French, T., 2012

Tritimovirus P1 functions as a suppressor of RNA silencing and an enhancer of disease symptoms. Virus Res. 163, 672-677. 